\title{
The ideological use and abuse of Freiburg's ordoliberalism
}

\author{
Malte Dold ${ }^{1} \cdot$ Tim Krieger $^{2}$ (D)
}

Received: 19 August 2019 / Accepted: 9 January 2021

(c) The Author(s) 2021

\begin{abstract}
In the aftermath of the Eurozone crisis, a battle of ideas emerged over whether ordoliberalism is part of the cause or the solution of economic problems in Europe. While German ordoliberals argued that their policy proposals were largely ignored before, during and after the crisis, critics saw too much ordoliberal influence, especially in form of austerity policies. We argue that neither view is entirely correct. Instead, we observe that the battle of ideas is largely independent of the countries' actual responses to the Eurozone crisis: pragmatic self-interest on behalf of governments rather than their ideological convictions played a crucial role in political reactions. We explain this dynamic game-theoretically and highlight a number of reasons for the decoupling of the political-pragmatic debate from the ideological-academic discourse. In addition, we argue that ordoliberals themselves contributed to the ideological misuse of their own program: the ordoliberal Freiburg School ceased to be an active research program and instead grew to resemble a tradition which all too often disregarded the international academic discourse, in particular in macroeconomics. As a result, ordoliberal thinking was abused by its proponents and critics alike to emphasize their preconceived Weltanschauung (worldview). We end our paper with some thoughts on how a contemporary ordoliberalism can be constructively used to react to some of the challenges of the ongoing Eurozone crisis.
\end{abstract}

Keywords Freiburg school · Ordoliberalism · Eurozone crisis · Austerity · Ideology

JEL Classification B29 $\cdot$ D43 $\cdot \mathrm{E} 61 \cdot \mathrm{G} 18 \cdot \mathrm{P} 16$

By ideology I do not mean a knowingly biased or inaccurate description of the way society works, or an attempt to bamboozle the populace with explanations that economists know in their heart of hearts to be false. I mean, rather, an earnest and sincere effort to explain society as its ideologists themselves perceive it: an effort to speak the truth at all costs. What is "ideological" about such an effort is not its hypocrisy but its absence of historical perspective, its failure to

Tim Krieger

tim.krieger@vwl.uni-freiburg.de

Malte Dold

malte.dold@pomona.edu

1 Economics Department, Pomona College, 425 N. College Avenue, Claremont, CA 91711, USA

2 Department of Economics, University of Freiburg, Wilhelmstr. 1b, 79085 Freiburg i.Br., Germany, and CESifo, Munich, Germany 
perceive that its pronouncements are a belief system, conditioned like all belief systems by the political and social premises of the social order.

Robert L. Heilbroner (1988, pp. 40-41)

\section{Introduction}

Ordoliberalism, ${ }^{1}$ which traces its roots to a prolific group of economists and legal scholars at the University of Freiburg's Faculty of Law and Economics in the early 1930s, has proved singularly influential in shaping the social market economy of post-war Germany. ${ }^{2}$ While the Freiburg School undeniably has German roots, it has been from the start "an integral part of the neoliberal network of scholars which formed in Vienna, London and Chicago during the interwar period" (Kolev 2019, p. 24; Köhler and Kolev 2013). Ordoliberal scholars were involved in important events like the Colloque Walter Lippmann in 1938 and the founding meeting of the Mont Pèlerin Society (Dold and Krieger 2019a), with Friedrich A. Hayek playing an important role in building bridges between the ordoliberals and other neoliberal communities (Kolev 2019). ${ }^{3}$

At its core, ordoliberalism endorses the idea that a stable legislative-or constitutional-framework is needed to protect both entrepreneurial competition and economic freedom for all private market actors (Dold and Krieger 2019b). It assumes that constitutional choices define constraints that effectively limit how market participants can pursue their own goals or, more generally, how markets function (Vanberg 2017). The emphasis on constitutional rules illustrates the similarity between the Freiburg School and James Buchanan's constitutional political economy. ${ }^{4}$ Similar to the logic of Buchanan's system, a core insight of ordoliberalism is that while the economic order is to be implemented and maintained by the state, the role of government is constrained to improving the economic order only "in an indirect manner, by shaping the rules of the game" (Vanberg 2017, p. 10). Or, as Sally (1996, p. 8) puts it, "(i)t is incumbent on the state to set up and maintain the institutional framework of the free economic order, but it should not intervene in the mechanisms of the competitive economic process."

This-admittedly very condensed characterization of the ordoliberal research program-suggests that ordoliberalism's core is a framework embracing mostly microeconomic and politico-economic ideas. It is therefore puzzling to see that a debate on the role of ordoliberalism in European macroeconomic policy started in the aftermath of the

\footnotetext{
1 In Germany, the term Ordnungspolitik commonly is used to describe economic policy inspired by ordoliberal thinking. However, "(t)he term 'Ordnungspolitik' is so typically German, that direct translation into English is almost impossible" (Ordnungspolitisches Portal 2019). In the following, we will stick to the term ordoliberalism to avoid possible confusions.

${ }^{2}$ Its founding fathers and chief proponents at that time were the economist Walter Eucken (1891-1950) and the jurists Franz Böhm (1895-1977) and Hans Großmann-Doerth (1894-1944). While those scholars were the main proponents of the Freiburg School, Alexander Rüstow (1885-1963), Wilhelm Röpke (18991966) and Alfred Müller-Armack (1901-1978) also count among the ordoliberal scholars of the first generation.

${ }^{3}$ During his time at the University of Freiburg (1962-1968 and after 1977), Hayek served as an elected director and later as honorary president of the Walter Eucken Institute (WEI), today's most important ordoliberal think-tank in Germany.

${ }^{4}$ Buchanan, too, acted as an honorary president of the WEI until his passing in 2013. See Kolev (2018), for a discussion of the parallels between Buchanan's constitutional political economy and the ordoliberal approach.
} 
Eurozone crisis, which began in 2009 and is still ongoing. On the one hand, German ordoliberals complained that their ideas and concepts for European recovery had been ignored by politicians (Krieger 2018). Rather than relying on or improving existing common rules of the European competitive order, thus keeping discretionary political intervention into the playing of the game weak, it appeared to ordoliberals that the political reaction to the crisis was dominated by national interests, logrolling and rent seeking, rather than the result of economic reasoning (Dold and Krieger 2017a).

On the other hand, critics accused ordoliberalism of being responsible for not resolving the Eurozone crisis in a timely fashion but prolonging the suffering of Eurozone members located on the European periphery by advocating growth-reducing austerity policies and structural changes (among others, Krugman 2014; Blyth 2015; Ryner 2015; van der Walt 2016). Moreover, the critics "in Anglo-Saxon academic journals and print media with little involvement of German economists ... [take it] for granted that ordoliberal thinking is a coherent intellectual Weltanschauung which provides 'an authoritarian, undemocratic and technocratic turn in European governance'" (Young 2015, p. 7; quote referring to Biebricher 2013, p. 345). ${ }^{5}$

Those contrasting perspectives on ordoliberalism and its role in the Eurozone crisis provide the backdrop against which the present paper sets out to discuss the ideological uses and abuses of Freiburg's ordoliberalism. More generally, we argue that the debate can be seen as an example of the various ways in which schools of economic thought become the object of ideologically motivated policy discourse.

The paper proceeds as follows. In Sect. 2, we will discuss the connection between ideology and economic schools of thought. Section 3 will clarify what we mean by the ideological abuse of ordoliberal thinking. In Sect. 4, we will recapitulate the origins and-so farunsuccessful attempts to solve the Eurozone crisis in order to demonstrate that national pragmatism, rather than ideology, spurred various political reactions to it. In Sect. 5, we will argue that it is neglect of the banality of the mundane that drove the ideological abuse of ordoliberalism from outside. In Sect. 6, we will discuss the contribution of representative German ordoliberals to the current debate. We will argue that their systematic disregard of the international discourse in macroeconomics contributed to the ideological abuse from within, leading to a self-enforcing interaction between the two forms of ideological abuse. In Sect. 7, we will explore future lines of research that may revive and sharpen (Freiburg's) ordoliberalism; i.e., we will explore the ideological uses of ordoliberalism. Section 8 will conclude.

\footnotetext{
5 To give just one example of what a typical article on the role of ordoliberalism during the Eurozone crisis looked like, consider Art (2015) with the telling title "The German Rescue of the Eurozone: How Germany is Getting the Europe it Always Wanted", published in Political Science Quarterly. In that 32-page paper, the only direct references to ordoliberal scholars are a text by Wilhelm Röpke, originally published in 1944, and another one by Alfred Müller-Armack, published in 1956 (note that no reference at all is given to scholars from Freiburg). For a synopsis of ordoliberalism, the author refers to a text by Ralf Ptak (2009), a left-wing economist without any connections to contemporary ordoliberalism (which, today, probably is best represented by Lars Feld and Viktor Vanberg, the current and the former director of the Walter Eucken Institute in Freiburg). Even more puzzling: In the sections on recent Eurozone crisis policies, the number of references drops substantially. In the section on the Outright Monetary Transactions (OMT) program, not a single reference is given, although many German economists have written on the issue.
} 


\section{Ideology and economics}

Settling on a definition of ideology is not an easy task. Typically, notions of ideology combine "a somewhat coherent, rather comprehensive belief system" (Higgs 2008, p. 538) with a specific set of implications for the ordering of real-world social phenomena. Hinich and Munger (1996, p. 10) summarize ideology as a belief system that "tells us what is good, who gets what, and who rules". Although Irving Fisher (1919, p. 10), in his annual presidential address to the American Economic Association, cautioned more than 100 years ago that "(a)cademic economists, from their very open-mindedness, are apt to be carried off, unawares, by the bias of the community in which they live", economic theory has surprisingly little to say about ideology (North 1988). ${ }^{6}$

At the same time, economics frequently has been accused of being ideological. In that regard, much of the critique of economics results from different views on the economy. While economic theory usually portrays the economy as a system, i.e., a social structure that functions analogously to the "affectless interactions of the physical universe", implying that its properties can be discussed in the neutral language of science (Heilbroner 1990, pp. 107-108), critics of economic theory often see the economy as a regime resulting from social hierarchies and communal relationships (Heilbroner 1990). ${ }^{7}$ Even if, like Schumpeter (1949), one rejects the idea that ideology necessarily involves a deliberate misrepresentation of social reality, evidently an asymmetry in the views exists on how ideological economics is: While economists believe in the field's scientism and the possibility of positive economics (see, e.g., Friedman 1953), critics think of it as a normative exercise in market liberalism (see, e.g., Foucault 2008). ${ }^{8}$

More practically, ideologies can be understood as selective or partial representations of a complex world (Heilbroner 1988, 1990) or a simplification of "a reality too huge and complicated to be comprehended, evaluated, and dealt with in any purely factual, scientific, or other disinterested way" (Higgs 2008, pp. 548-549). In economics, the standard for careful scientific work is met when plausible generalizations are supported by robust data. The combination of theory and evidence, economists believe, delivers important insights into how the economy works. However, the evidence may be inconclusive, and a specific class of models may not be the only possible representation of the observable behavior of economic agents. Inconclusive evidence leaves economists with the task of choosing reasonable models and interpreting their findings, which is a difficult challenge because the theoretical presuppositions as well as the political views of the researcher lead to value- or theory-laden explanations (Hands 2001, pp. 107-109). Or, in Weintraub's (1990, p. 122) words: economic "[s]cience makes worlds, not discoveries". For instance, economic policy

\footnotetext{
6 The origins of ideological commitments, typically explained by interest theories ('ideology helps people pursue wealth or power') or strain theories ('ideology helps people flee from socioeconomic anxieties'), have mostly been discussed from anthropological or sociological perspectives (e.g., Geertz 1973; Higgs 2008).

7 While we refer to Heilbroner's conceptual approach to ideology here, we do not want to engage in the debate on his - heavily disputed - claim of economics being an ideology; for details, see Weintraub's (1990) comment on Heilbroner (1990).

${ }^{8}$ Our paper reflects on a debate that takes place mostly between (ordoliberal) economists and non-economists (mostly from other social sciences). Below we also will touch on the different views of ordoliberals and many (new Keynesian) macroeconomists on European economic policy. One should not forget, however, that major, ideologically framed debates arise within economic science as well. It is beyond the present paper's scope to discuss that debate (for a summary, see Javdani and Chang 2019).
} 
experiments such as macroeconomic reforms cannot be repeated under different environmental settings (like in many natural sciences) and compared on that basis. ${ }^{9}$ Hence, the lack of counterfactuals makes it impossible to know whether a particular reform policy achieves the best possible outcome compared to other reform options, leaving the door wide open for ideologically framed interpretation.

Within a specific interpretive community of scholars (e.g., the ordoliberals, the monetarists, the post-Keynesian macroeconomists), an ideology is shared, defined and supported by selective evidence and constructed theories (Weintraub 1990): it ends up having its texts, theories and arguments, thus aligning with Higgs's (2008) argument that ideology has four main aspects: $i$. cognitive (it structures a person's perceptions); ii. moral (it tells the person whether a social conduct at hand is good or bad); iii. programmatic (it propels the person to act in accordance with his or her moral assessments), and $i v$. solidary (it reflects the solution of an inherent collective action problem). A group, or rather school of thought, forms successfully, if a sufficient number of people experience (psychological) benefits, such as comfort and senses of belonging, by being members and sharing a common ideology.

Scholars of different ideological camps often enter into fierce debates without acknowledging that some of their ideological differences are driven by common functional drivers. According to Hinich and Munger (1996, p. 236), "[i]deology is not nonrational, it is not a residual or random component of conscious human decision making". Instead, ideological positions serve crucial functions for their respective group members independent from the truth-content of their theories: 'Group identity, the understanding of labels such as 'left,' 'conservative,' or 'Christian Democrat,' indeed, the very essence of political communication, requires ideology, and cannot exist without it".

What is important is that different camps of scholars arguing in favor of their own ideologies or ideologically framed policy proposals need to convince policymakers as well as voters outside their peer groups. In that respect, ideology inevitably becomes intertwined with rhetoric, understood as "the whole art and science of argument, the honest persuasion that is good conversation" (Klamer and McCloskey 1988, p. 10). While pure academic discourse arguably may come close to resembling an exercise in honest persuasion, (distributional) stakes tend to be much larger in academic discourse carrying political implications. Therefore, those debates among academics and public intellectuals most likely do not result in a struggle over ideas but rather a battle of ideas. Against that backdrop, it does not come as a surprise that Brunnermeier et al. (2016) call their remarkable book on the Eurozone crisis "The Euro and the Battle of Ideas".

To the surprise of many ordoliberal scholars, critics claim that Freiburg's ordoliberalism is one of the major participants in that very battle of ideas. Good reasons can be found for doubting the presumed impact of ordoliberalism on European policy outcomes, despite the opposite claim by "an avalanche of scholarship from disciplines as diverse as macroeconomics, political theory, law, sociology of science, literary studies, or finance" (Kolev 2019 , p. 23). However, as we will explain, the Freiburg School indeed suffers from the same problem that any school of thought is likely to have when it turns into a mere tradition (Dyson 2017) rather than being an active research program: it may fall victim of being used and abused as an ideology. More specifically, we will investigate how uses and abuses of Freiburg's ordoliberalism may occur both from within and from outside that tradition.

9 This is reminiscent of Lucas's (1976) critique. 
Here, within refers to participants in public debates who argue along ordoliberal lines, including ordoliberal scholars themselves; the outside consists of critics of (supposedly) ordoliberal thinking.

\section{The abuses of ordoliberal thinking}

Ideological abuses from within frequently could be observed during the Eurozone crisis. By that we mean arguments in the public discourse that are framed in an ordoliberal sense. For example, the Swabian housewife, ${ }^{10}$ who never spends more than what she saves, has become the symbol of seemingly ordoliberalism-dominated crisis management characterized by German demands for austerity (Hien 2017). Furthermore, some politicians and public intellectuals abused their ordoliberal positions when they simply accused Southern European countries of breaking the rules by following their lazy mentalities and eschewing structural reforms. For instance, they connect their ordoliberal complaints about southern Europeans' reluctance to reform by labelling those countries Club Med (see, e.g., Berthold 2017), thereby evoking images of premium all-inclusive holidays (Club Med is a private company offering high-end vacation packages and running many Mediterranean Sea resorts). ${ }^{11}$

From outside, the ideological abuses appear as strong critiques of ordoliberal ideas rarely based on a sound reading of the school's defining texts. Critics often project their own ideological categories onto the ordoliberal school of thought. In doing so, they reassure themselves of the correctness of their own Weltanschauung or, possibly, supreme values. Denouncing a school of thought as an ideology (in a more negative sense than Heilbroner and others do; see above) is a classic means of achieving opinion leadership in a fierce public debate (e.g., Freeden 2006). ${ }^{12}$ In the current debate, a striking example of that form of ideological abuse can be found in an article by van der Walt (2016), whose arguments suggest very simplistic social mechanics that run from ordoliberalism to jihadism. According to the author, protestant ethics led to ordoliberalism (several members of the Freiburg School indeed were protestants), which resulted in imposed austerity in France and ultimately jihadist terrorism. Dold and Krieger (2017a) argue that van der Walt's clash of religions story is inaccurate on both fronts: it betrays a lack of knowledge of ordoliberalism and of jihadist terrorism. Owing to the simplistic character of the statement, a good reason can be found for assuming that van der Walt's claim of ordoliberalism being an ideology actually emanates from attempting to disguise the ideological core of his own argument.

However, an important remark must be made here. Both types of ideological abusesthe one from within and the one from outside-tend to complement and reinforce one

\footnotetext{
10 After the collapse of Lehman Brothers in 2008, German chancellor Angela Merkel stated: "One should simply have asked the Swabian housewife. ... She would have told us that you cannot live beyond your means" (cited by King 2015, p. 29).

11 A conclusion very much in line with German chancellor Angela Merkel stating in 2011 that "(i)t is also important that people in countries like Greece, Spain and Portugal are not able to retire earlier than in Germany - that everyone exerts themselves more or less equally. ... We can't have a common currency where some get lots of vacation time and others very little. That won't work in the long term." (Der Spiegel 2011).

12 As Freeden (2006, p. 4) writes: "the term [ideology] is very common, though not beloved, among scholars, writers and academics, and it has an illustrious pedigree, although regrettably also a notorious one. ... We find it in the 'slash and destroy' mode when used to rubbish another point of view.".
} 
another. The less reflective a school becomes from within and the more it tends to criticize other opinions on ideological grounds, the more likely is an ideological backlash from the outside. Often it remains unclear who actually started the ideological dispute. Take, for example, the German economists and politicians who sense "moral hazards at every turn" (Landmann 2019). An inappropriate simplification of the living conditions of poor and elderly Greeks suffering severely from austerity programs may lead, as a matter of course, to a harsh response from critics.

At the same time, it certainly is not conducive to a reasonable exchange between both sides when Münchau (2014) talks about the "wacky economics of Germany's parallel universe ... German economists roughly fall into two groups: those that have not read Keynes, and those that have not understood Keynes." Statements like that preclude any debate on how highly complex economic problems ought to be solved by-necessarily highly complex-economic reforms. Since the solution to the Eurozone crisis requires economic expertise but also touches on significant national interests regarding massive distributional issues, a simplistic ideological answer seems inappropriate. Hence, on both sides of the debate, ordoliberalism appears - at least to some degree - to be "overused and undertheorized" (Young 2015, p. 11).

In the following, we will investigate the debate on the role of ordoliberalism in the Eurozone crisis in more detail. On the one hand, we will show that German politicians indeed have claimed that their policy measures rest on an ordoliberal foundation. We will argue that that position neither is backed by early ordoliberal theoretical writings nor by more recent ordoliberal scholarship, which often lacks expertise in macroeconomics and financial market economics. The term ordoliberalism has been used as if it were a "tradition ... associated with a certain mindset" (Dyson 2019, p. 91, 2017), which combines elements of the main lines of ordoliberal thinking from the past, but also convenient personal interpretations of what ordoliberalism ought to be in the present.

On the other hand, we will show that critics of German economic policy find it all too convenient to identify ordoliberalism as the culprit for justifying their general dislike of the German political position. They ignore that solving the Eurozone crisis involves enormous costs that need to be shared among EU member states. Given the complex interplay of responsibilities (Krieger 2016), it is not easy to identify fair shares of burden between the 'irresponsible' Southern European debtors and the 'careless' German investors. Since in a democratic European Union, which honors member states' sovereignties and their national policy interests, deciding on other countries' public finances is not an option, moral pressure is used as an attempt to increase the burden on German investors by means, inter alia, of implementing Eurobonds and a more integrated fiscal policy on the EU level.

\section{Political responses to the Eurozone crisis: pragmatic, not ideological}

It lies beyond the scope of the paper at hand to discuss the root causes and origins of the Eurozone crisis in detail. ${ }^{13}$ It likewise is not necessary for the argument presented herein to provide a precise account of the EU- or country-level policy measures during the height of

\footnotetext{
13 Various extensive accounts of the developments can be found in, e.g., Sinn (2014) and Becker and Fuest (2017). Ultimately, the latter identify a commitment problem at the heart of the crisis, because most European legislation and treaties for the EMU were fair-weather politics that no longer were suitable in times of crisis.
} 
the crisis. More relevant for our analysis is the character of discussions about crisis resolution and the development of a new European institutional framework for avoiding future crises. In that context, we are interested in why (at least) two camps are fighting a battle of ideas (Brunnermeier et al. 2016) instead of solving actual economic problems (note that the new institutional framework that Eurozone member states are working on is all about future, not current, crisis resolution). Our argument is that governmental self-interest, i.e., the minimization of economic and political costs, is the main driver for a slow crisis resolution, not the ideological differences portrayed in academia or the media.

Aware of our own ideological biases, we argue that governments' slow crisis resolution in the Eurozone reasonably can be explained game-theoretically by a war of attrition or chicken game (Schimmelpfennig 2015; Krieger 2016). That game is a variant of a timing game characterized by a last-mover advantage (Brunnermeier and Morgan 2010; Bulow and Klemperer 1999; Fudenberg and Tirole 1991; Osborne 2003). The game involves two contestants, Country A and Country B, who compete for a valuable resource. They do so by resorting to a wait-and-see strategy because the contestant, or government, that moves first and reveals its strategy is fated to be the loser (see payoff matrix in Fig. 1, with $\alpha>\beta>\gamma>\delta$ ).

The main problem with the game is that the players continuously accumulate costs for the entire duration of the contest. In other words, while both players individually have an incentive to wait so that they do not have to give in, that strategy leads to the worst possible collective outcome $(\delta, \delta)$.

In the Eurozone, the 'prize' of the war of attrition was, and is, to minimize one's own costs of crisis resolution. Given that substantial costs eventually will materialize, they have to be paid by some country (or, more specifically, by its citizens who may-as voterspunish their government for too costly bargains) at some future time. That consequence implies that, ultimately, distributional issues of burden sharing are at stake, which directly challenge the member states' legislative prerogatives to determine their fiscal policies independently. Trying nevertheless to act independently, governments of the crisis countries on the European periphery (in particular, Greece, Spain and Italy) often decided to delay the implementation of structural reforms until assistance from the core (notably, Austria, Germany and the Netherlands) arrived-which ultimately was not forthcoming. At the same time, the governments of the core countries preferred to wait for stabilizing structural reforms to be implemented at the periphery in order to minimize their own economic and political costs.

Yet, delay increased the negative macroeconomic effects of the crisis. The costs of the crisis rose more quickly for the less resilient Southern European countries, driving up their costs of waiting further. Delaying put countries like Greece in weaker positions than the post-crisis economic powerhouses in Europe, in particular Germany. Considering the efforts at the European level to resolve the crisis, Schimmelpfennig (2015, p. 177) concludes that " $[w]$ hereas negotiations produced a co-operative solution averting the breakdown of the euro area and strengthening the credibility of member state commitments, asymmetrical interdependence resulted in a burden-sharing and institutional design that reflected German preferences predominantly." One does not have to agree with that conclusion but the Greek population-without doubt-did not fare well in the process of crisis resolution.

The position of a country, i.e., its threat point, in the Eurozone crisis-resolution bargaining game, depended (and still depends) not on economic performance alone but also on other factors. First, the time dimension is crucial. Immediately after the crisis started, the uncertainty about the financial linkages between banks, insurance companies and 
other financial players of the Eurozone member states was enormous and so was the fear that macroeconomic instability and even state insolvency could spill over to neighboring countries. The uncertainty put countries that were candidates for negative macroeconomic outcomes in a relatively strong position. As time passed, however, cross-border financial involvement decreased and the resiliences of national financial sectors increased. Second, the sheer size of national economies affects their relative strength in bargaining. Compared to Greece, Spain was given much more favorable conditions regarding economic reforms; today, Italy is still seen as a threat to financial stability in the Eurozone. Third, whether or not an economy is a key market for the game's dominant player might affect bargaining as well. For instance, France always has been treated quite favorably during the Eurozone crisis, despite its budgetary problems. In fact, while pushing for a tough stance on some highly indebted countries, Germany in particular had a self-interest in not losing the French or Spanish markets for exports. In sum, while advantages existed for countries that survived the crisis easily, mainly in the early years after the crisis, the more heavily affected countries strategically were on equal footings, thereby allowing more balanced steps toward crisis resolution if not for shortsighted policies that were driven by narrowly construed national interests. Countries played out their threat points because they believed that they could minimize the costs of crisis resolution for themselves. Yet, that strategy just led to more waiting and more macroeconomic damage.

The shortsighted self-interests of political actors, epitomized by German chancellor Angela Merkel's expression "driving by sight" (quoted by Zestos, 2015, p. 146), not necessarily their steadfast ideological fundamentals, played a pivotal role in prolonging the crisis. Feld et al. (2015) state rightly that "German economic policy was simply a pragmatic response to different crisis phenomena. ... German pragmatism during the crisis has caused an unintended break of basic principles of ordoliberalism-surrendering EMU's de-politicised monetary constitution against the prevention of further fiscal integration on the EU level." 14 In the same vein, Burda (2015) adds that "[i]t is not ordoliberal religion, but a mixture of national self-interest and healthy mistrust informed by experience that guides German economic policy today." The latter remark refers to the experience with Germany's federal structure in which joint liability for each state's debt led to everincreasing debts: "Understandably, moral hazard becomes a categorical imperative." Or, as Kluth (2018) puts it, "within Germany, rich Bavarians are already fed up with bailing out indebted Berliners, and Germans don't want to replicate this 'transfer union' in the EU." The fear of further bailouts and deeper fiscal integration-be it through Eurobonds, joint deposit insurance or other transfer union-like means-drove, and drives, Germany's position in the negotiations about the resolution of the Eurozone crisis.

In the following section, we will argue that the neglect of the role of national pragmatism led critics of ordoliberalism to overstate the role of ordoliberal ideas in managing the Eurozone crisis. Ultimately, we think that failure to acknowledge the banality of the mundane drove the ideological abuse of ordoliberalism from outside. However, we also will argue subsequently that the intellectual history of German ordoliberalism (especially in form of a systematic disregard for international discourse in macroeconomic theory as well as a fixation with rules and balanced budgets) contributed its fair share to the ideological abuse from within.

\footnotetext{
14 The pragmatic response driven by German national interests surely merits its own in-depth analysis. Yet, that analysis lies beyond the scope of the present paper (but it is nicely explored in, e.g., Feld et al. 2015).
} 


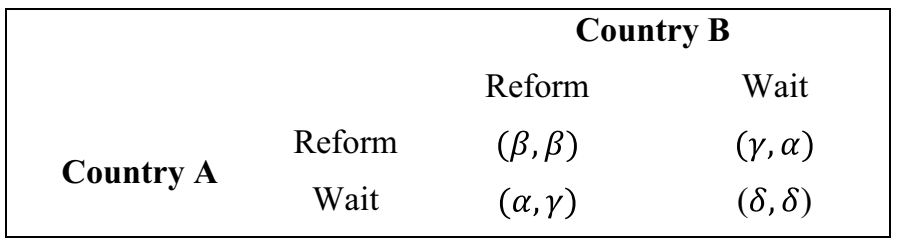

Fig. 1 Eurozone crisis-resolution bargaining game (war of attrition)

\section{Pragmatism? Egoism? Neoliberalism? ... Ordoliberalism!}

Many articles criticizing the role of ordoliberalism in the current Eurozone crisis ultimately are driven by an attempt to clarify or interpret the German response to the crisis. More specifically, the critics try to make sense of Germany's seeming passion for hard currencies, low public debts and high national savings rates. Those factors are suspected to direct German demands for austerity, i.e., its call for deflation of prices, wages and public debts in crisis countries in order to regain competitiveness or investors' trust (Blyth 2015; Dold and Krieger 2017a, b).

In spite of the convincing arguments that identify national pragmatism and self-interest at the heart of German crisis policies-think, for instance, of the bailouts of major German banks (see Feld et al. 2015; Krieger 2016) — many critics of ordoliberalism shy away from accepting or seeing that point. In the aftermath of World War II, pragmatism, egoism or even nationalism usually were not seen as opportune descriptions of German policies. Rather, Germans were regarded as the most ardent supporters of European integration and, indeed, they fulfilled that role by being one of the major net financial contributors to the EU budget. However, with a new generation of politicians in the post-Helmut Kohl era, who did not experience the war and who were (and are) elected by voters who take peace in Europe for granted, national economic self-interest increasingly trumped beliefs that European integration is first and foremost a peace project, which changed Germany's political role in Europe but was not necessarily recognized by the European public. ${ }^{15}$

Another potential reason why critics were not willing to accept the argument of national pragmatism might be the fact that one can apply the same logic, in principle, to any country in the world. Therefore, Dold and Krieger (2017a, b) call the argument of national pragmatism the litmus test of the current critique of ordoliberalism: would France, for instance, react differently if it were in a situation similar to Germany? Would France guarantee public-sector loans or debt relief to countries with histories of national insolvency? Of course, we do not know the answer to that hypothetical question. However, if ordoliberalism is responsible for the German support of austerity policies, France would have to react fundamentally differently to the current challenges (e.g., by a call for the collectivization of national debts). One can doubt whether that would indeed be the case.

In addition, it is far-fetched to accuse German crisis management for being too neoliberal, as some of the critics of ordoliberalism have charged (see, e.g., Van der Walt 2016;

\footnotetext{
15 In fact, many observers were surprised when Germany assumed not only economic but also political leadership during the Eurozone crisis. Traditionally, Germany and France split their leadership roles, with France leading politically and Germany economically.
} 
Bonefeld 2012). ${ }^{16}$ German post-WWII politics is committed to the idea of a social market economy with a strong state that guarantees social security and prevents the concentration of market power. The German economic model rightly was called Rhine capitalism by Albert (1993) since it favors the model of a social market economy. Rhine capitalism can be contrasted with the American model of a pure market economy which, at least at the outset, put less emphasis on the notion of social justice or the idea of greater economic equality. Hence, the term neoliberalism (or for that matter, market liberalism) should rather be associated with the Anglo-American version of capitalism that has its intellectual roots in Chicago School economics, with its most famous proponent Milton Friedman, whose pro-market thinking differs from that of German ordoliberals like Walter Eucken or Franz Böhm (Dold and Krieger 2017a, b; Young 2017).

In their search for a specific Germanic element that could explain the political reaction of Germany to the Eurozone crisis and that was not confined to the ideas of national pragmatism or neoliberalism, critics singled out ordoliberalism. Since its intellectual roots lie in Germany (more specifically in Freiburg) and since some of its core theses - such as the inseparable connection between freedom and liability-were propagated repeatedly by German politicians, economists (see Sect. 3 above), and the media, critics were sure to have found the scapegoat for the puzzling German reactions to the Eurozone crisis. Young (2015) labels the behavior of the critics the hijacking of ordoliberalism in the sense that they project all types of bad features onto ordoliberalism (such as a Teutonic obsession with rules or saving), without trying to understand the theoretical and normative core of the research program. While well aware that our explanation is broad, we nevertheless believe that hijacking explains the essence of the ideological abuse of ordoliberalism from outside.

One should not ignore, however, that German economic policy exhibits certain historically and institutionally shaped characteristics and beliefs that supply fertile ground for critics. For instance, German policy-makers often emphasize a national preference for low inflation rates resulting from the country's experience with two major episodes of inflation (the hyperinflation of 1923 and the suppressed inflation of 1948). ${ }^{17}$ From a Keynesian perspective, low inflation does not appear to be very helpful in fighting unemployment. High savings rates, as seemingly preferred by the Swabian housewife, have been deemed typically German, too: "Welcome to Germany: Erst Sparen, dann Kaufen!" (Blyth 2015, p. 132; German in the original text). ${ }^{18}$ According to Blyth (2015, p. 216), from there it is only a small step toward "Kein Kaufen, nur Sparen!", 19 a "very ordoliberal/Austrian slogan", which again clearly runs counter to any Keynesian approach to crisis resolution.

Finally, a more current German experience involved the economic bust in the early 2000s, when Germany was dubbed the sick man of the Euro. Economic reforms and wage restraints, i.e., austerity measures, were adopted to recover from that crisis, but not without

\footnotetext{
${ }_{16}$ For instance, Bonefeld (2012, p. 633) writes: "the study of ordoliberalism brings to the fore a tradition of a state-centric neoliberalism, one that says that economic freedom is ordered freedom, one that argues that the strong state is the political form of free markets, and one that conceives of competition and enterprise as a political task." In addition to the claim that ordoliberalism is neoliberal (here meaning radical market fundamentalism), Bonefeld connects the ordoliberals' quest for a strong state with Carl Schmitt's notion of a strong state, which "if read in isolation, may sound undemocratic or even anti-democratic" (Young 2017, p. 136; Vanberg 2015). For an extensive reflection on such a problematic comparison, see Berghahn and Young (2013).

17 However, no particularly strong empirical evidence supports this claim (e.g., Shiller 1997).

18 "Erst sparen, dann kaufen" = "First save before you buy".

19 "Kein Kaufen, nur Sparen" = "No buying, just saving".
} 
high political and social prices to be paid. ${ }^{20}$ In fact, such policies-although perceived as hard and sometimes unjust-were believed to have formed the basis for Germany's laterand ongoing-economic success. ${ }^{21}$ That success story appears to many Germans as a useful model for restoring economic success in the European crisis countries of today, again meaning that national experiences and pragmatism are the drivers of policy proposals, not deep commitments to ideological principles. Such thinking is reminiscent of the projection of Germany's Social Market Economy as a role model for successful economic policy in general (and in Europe specifically). As Tribe (1990, pp. 631-632) concludes: "The term [social market economy] did after all gain definition only after economic recovery was under way in the Federal Republic, and has consequently since then been associated with the more positive aspects of German economic development. In this way the principles of the 'social market economy' have become identified with whatever is thought to have been fundamental to the successes of the postwar German economy." We will return to that point when considering the ordoliberal perspective on crisis resolution in the next section.

\section{The fair share of German ordoliberals}

The debate about the role of ordoliberalism in shaping German crisis politics shows how problematic it is when research programs do not keep up with or take part in international academic discourse. The aforementioned critique of ordoliberalism could get out of hand because ordoliberalism largely is an unknown intellectual tradition outside of Germany. Some critics point out - whether justly or unjustly - that over time German ordoliberalism became "more fundamentalist ... and less interpretive" (van der Walt 2016, p. 80). For instance, it is important to recognize that Eucken's constituting principles of a competitive order (viz., a functioning price system, the primacy of the monetary order, open markets, private property, freedom of contract, liability, and continuity of economic policy) are to greater or lesser extents components of any efficient economy. However, without any theoretical qualification or empirical weighting in concrete cases (e.g., economies in transition), Eucken's principles might be reduced to mere dogma.

One of the unfortunate features of ordoliberal scholarship has been its neglect of ongoing debates in contemporary macroeconomics. Bachmann (2019, p. 117) points out that a "[f]ocus on microeconomics, if not the mathematical methods, is entirely consistent with ordoliberal ideas". The fact that economic theory has always enjoyed a particular prestige in German academia "meant a long-lasting dearth of applied macroeconomic theory and empirical macroeconomics in Germany" (ibid.). Furthermore, Bachmann points out that many German economists of an ordoliberal tilt are convinced that Anglo-American macroeconomics equals Keynesianism and leftwing economic policy. Again, like the opponents who ascribed all sorts of bad policies to ordoliberal economics, we see an ideological reduction on the opposite side by ordoliberals themselves. The reductionist and moralizing feature of academic policy-discussions contributed to the battle of ideas described above that largely was independent of concerns for concrete crisis resolution. In addition, the fact that some ordoliberals after Eucken simply equated a functioning market economy with the realization of business interests (Braunberger 2016), while neglecting the fact that exit and

\footnotetext{
${ }^{20}$ Among other things, the German Social Democrats (SPD), who were held responsible for the reforms, saw some of their members and clientele defect to a new leftwing party (Die Linke).

21 For a more balanced view of the narrative, see Dustmann et al. (2014).
} 
voice on behalf of the workers and consumers is a necessary prerequisite for performance competition (Leistungswettbewerb), did not help to enhance their scientific reputations. ${ }^{22}$

While Bachmann and Braunberger rightly criticize ordoliberal economists' lack of empirical research, Landmann (2019) points out that ordoliberalism emphasizes price stability and liability on the micro level, but it neglects the role of fiscal policy in securing macroeconomic stability on the national or supranational level. The reason is, according to Landmann (2019, p. 163), that "ordoliberalism was designed as a rulebook for running a market economy, not as a blueprint for the architecture of a currency union". Owing to its historical roots, ordoliberals of today tend to neglect the macroeconomics of the Eurozone at large. At the end of his assessment of ordoliberalism, Landmann ibid., p. 164) urges that "it is at times hard to shake off the impression that the respectability of ordoliberalism is used as cover for a thinly veiled nationalist conservatism."

Indeed, some macroeconomic arguments that have been proposed under the label of ordoliberalism appear precarious. ${ }^{23}$ Burda (in The Economist 2015) and Krugman (in the New York Times 2014) point out that the logic of the Swabian housewife no longer applies when the aggregation step is made. If all individuals and governments in the Eurozone cut spending at the same time, aggregate demand may fall to such an extent that any microeconomic reform will be overcompensated. Even if one does not follow such Keynesian logic, the idea that all members of the Eurozone could run current account surpluses at the same time (after implementing austerity measures successfully) is hardly convincing. Krugman (2014) calls that logic ordoarithmetics: "As [the Germans] see it, their economy was in the doldrums at the end of the 1990s; they then cut labor costs, gaining a huge competitive advantage, and began running gigantic trade surpluses. So their recipe for global recovery is for everyone to deflate, gaining a huge competitive advantage, and begin running gigantic trade surpluses. You may think there's some kind of arithmetic problem here, but in Germany they have their own intellectual tradition."24

Another macroeconomic misinterpretation has been made on the German (ordoliberal) side. If one recapitulates how the crisis evolved, one observes that a part of the quick postcrisis economic recovery in Germany was driven by capital inflows owing to Germany being more of a fiscally stable safe haven than the European periphery. Germany benefitted

\footnotetext{
${ }^{22}$ Eucken himself was well aware of the crucial role of performance competition for the efficiency and stability of the economic order. Eucken (1949) argued against prevention competition (Behinderungswettbewerb), i.e., a market order that prevents competition from other producers - or, for that matter, consumers' reactions. Eucken's approach combines ideas of coordination by the invisible price mechanism with 'record-type games' that incentivize excellence, while rejecting 'struggle-type games' that determine the winners of zero-sum games (Dold and Krieger 2017b).

${ }^{23}$ While one has to be careful with generalizations, we think some policy proposals put forth by ordoliberals depict oversimplifications of macroeconomic theory and policy akin to those of the supporters of modern-monetary theory (MMT). For a summary and critique of the latter, see Palley (2015).

${ }^{24}$ In the debate on the best means to solve the mostly macro-level crisis, two schools of thought indeed seem to oppose one another and neither of them is willing to give in. The respective policy conceptions differ remarkably; in the words of Brunnermeier et al. (2016, p. 4): "The northern vision is about rules, rigor and consistency, while the southern emphasis is on need for flexibility, adaptability and innovation. It is Kant versus Machiavelli. Economics have long been familiar with this kind of debate and refer to it as rules versus discretion." In this respect, it is also a debate between (self-declared) ordoliberals and (often) Keynesian pragmatists about the willingness to use taxpayer's money for quick crisis resolution by way of aggregate demand management. Against that backdrop, van der Walt's (2016, p. 88) argument that Southern Eurozone member states "have long traditions of relying on morally and politically quite acceptable combinations of state debt and inflationary measures to sustain socio-economic coherence and minimum levels of social equality" sounds quite provocative to the Swabian housewife.
} 
from a widening interest rate spread with the rest of Europe and devaluation of the Euro. Hence, the German belief that self-imposed austerity measures in the early 2000s are the reason for today's economic success is only partially true. A reason for Germany's fast recovery also can be found in the weaknesses of other European economies, implying in turn that the current economic situation in Germany is abnormal, a consequence of the crisis, rather than self-made. Once the Eurozone as a whole overcomes the crisis and recovers economically, Germany will lose some of its competitive advantage. In that respect, requests for more public spending in Germany may not be entirely misinformed. Additional spending on infrastructure (but, obviously, not on government consumption) could have helped to sustain German competitiveness and to support European neighbors at the same time, but was not an option from the point of view of German politicians in the aftermath of the crisis.

As the last point indicates (and as mentioned in Sect. 3), the broader debate might indeed have an important ideological component that goes beyond the discussion of theoretical details. During the crisis, German politicians lectured about the sizes of public debts in countries like Greece and Italy. Hardly surprisingly, the most popular explanation in Germany for the Eurozone crisis was the narrative about non-sustainable public debts being responsible for the economic problems of the southern European countries (Becker and Fuest 2017). Against that backdrop, it is easy to see high debt countries as having moral obligations to earn support from the German state. In fact, the German word for debt (Schuld) has two meanings: debt and guilt. In a moral or even religious sense, it is only a short step from guilt toward sin. Some scholars have pointed out that Eurozone disputes also may be interpreted as conflicts between — catholic_-debt 'sinners' in the South and - protestant—debt 'saints' in the North (e.g., Hien 2019). Josef Hien, in a lecture at the University of Freiburg in 2017, asked provocatively whether ordoliberalism is "protestant medicine against catholic dissoluteness".

\section{A revival of ordoliberal 'ideology'}

Having highlighted, so far, the ideological abuses of ordoliberalism, it remains to be asked whether-more positive-uses of that school of thought are possible, too. As the title of the present article suggests, we believe that positive uses of ordoliberal ideology indeed are available. In line our Heilbroner epigram at the outset and Freeden's (2006) rehabilitation of the term ideology as an analytical tool, ${ }^{25}$ we are convinced that ordoliberalism has much to contribute to the current debate about the future of the Eurozone. In particular, ordoliberalism can bring political and normative thinking back into a discourse that is dominated primarily by economic technicalities.

However, in order to do so, it is essential that ordoliberalism returns to being an active research program that focuses on its competitive advantage, viz., a combination of economics with politics, positive insights with normative reasoning, and theoretical idealization with applied policy recommendations. The normativity of ordoliberalism, or call it the ideological ordoliberal representation and interpretation of a

\footnotetext{
${ }^{25}$ Freeden $(2006$, p. 21$)$ states that "the rehabilitation of ideology both as social phenomenon and as analytical tool has shifted it from just a class or mass occurrence to a general feature of political thinking. It has removed it from the marginalized and ethically suspect shadowlands of its past existence and enabled it to claim recognition as the archetype of political thinking."
} 
complex world-regardless of whether one agrees with its positions or not-is actually its strength because it makes its ethical assumptions explicit. Ordoliberal theory is built on a normative commitment to liberal values (such as individual opportunities for economic and political participation) and a moral—not solely economic-defense of free, open, and competitive markets (Dold and Krieger 2019c). The normativity of ordoliberalism can be seen as an argumentative advantage in the current debate: policy implementation needs to be supported by the European citizenry whose approval of reforms will not only rest on theoretical economic efficiency concerns, but ultimately depend on moral arguments that go to the heart of what it means to live together as a European community.

\subsection{The ideals of consumer and citizen sovereignty}

At its core, ordoliberalism is built on the moral idea that the legitimacy of collective action stems from the consent of the individuals involved. In his advancements of Eucken's ideas, Vanberg (1997a, 2005) points out that that starting point leads to the ideals of consumer sovereignty in market settings and citizen sovereignty in political processes. While consumer sovereignty (i.e., the extent to which markets satisfy consumer preferences) is seen as the normative benchmark for judging the economic game, citizen sovereignty (i.e., the extent to which institutions reflect the will of the people) forms the normative benchmark of the political game. Vanberg's interpretation means that it is the individual in his or her role as a consumer and citizen whose agreement defines the legitimacy (and relative efficiency) of a given mix of economic and political rules.

While such a contractarian starting point is not necessarily unique in political economy (it is, for instance, part and parcel of the logic of constitutional economics; see, e.g., Buchanan 1987), it contributes to a democratization of ordoliberal economic policymaking by transcending the top-down character of Eucken's constituting principles. Following Vanberg, a contemporary ordoliberalism shifts the role of the political economist from being a technocratic expert to an adviser in the process of identifying a suitable institutional structure in which individuals can best govern themselves to their mutual advantage. Therefore, contemporary ordoliberalism abstains from imposing a liberal economic agenda on unwilling citizens but enters a public debate where it is only one among many contenders in an open democratic discourse whose ultimate arbiter is the European citizenry.

The crucial question that contemporary ordoliberals have to answer is how emphasis on individual sovereignty translates into policy recommendations in the face of the ongoing crisis in the Eurozone. While now is not the place to discuss policy proposals in detail (for an in-depth discussion, see Dold and Krieger 2019c), we think that two main implications can be drawn. First, at the bottom of the income distribution, ordoliberal reasoning invites the implementation of policies that enable individuals' competent participation in market transactions and political discourse. At the top of the income (and political power) distribution, ordoliberalism recommends the implementation of institutions that secure performance competition to hamper political capitalism, i.e., the concentration of economic and political power (see, e.g., Krieger and Meierrieks 2016). The idea is that working at both ends of the income and power distribution will strengthen consumer and citizen sovereignty. 


\subsection{Socioeconomic cleavages and ordoliberal responses}

Currently, the European Union is built on a fundamental asymmetry: the benefits of open borders and economic integration are distributed unevenly, favoring a well-educated and mobile urban elite as well as capital owners (Rodrik 2018). From an ordoliberal perspective, the systematic disadvantages of certain social groups (e.g., low-skilled workers and the rural population) likely will produce outcomes that are not conducive to a stable social order. Socioeconomic cleavages can lead to conflictual forms of competition wherein disadvantaged market participants invest in conflict activities aimed directly at damaging more powerful social groups (e.g., in the form of protest voting for anti-system parties). In addition to the efficiency loss from socioeconomic cleavages, economic imbalances can create political imbalances when certain societal groups define the rules of the political game. Such politico-economic power concentrations can become problematic for the broadly shared realization of social welfare goals (Eucken 1952, pp. 175-179). ${ }^{26}$

Contemporary ordoliberal policies would aim at dispersing power concentrations by fostering competition in the economic and the political realms. In markets, that means the advocacy of consequent antitrust legislation with the aim that competition works as "the most magnificent and most ingenious instrument of deprivation of power in history" (Böhm 1960, p. 22). As such, the European Commission should continue its tough stance on policing economic mega deals between industrial conglomerates and it should continue to deepen the harmonization of the regulatory framework for individual privacy and data protection (along the lines of the General Data Protection Regulation). In this context, it is crucial that ordoliberals take seriously the public choice literature which highlights that antitrust laws often fail to protect consumers against unwarranted exercises of market power due to the influence of special interests on antitrust legislation and enforcement (Shughart and McChesney 2010).

In politics, ordoliberals argue often that the best way to disperse political power is the active participation of the public in political decision-making processes, thereby reducing the likelihood of permanent winning coalitions (Vanberg 1997a). In order to foster political participation, ordoliberalism embraces the idea of the principle of subsidiarity. According to that principle, political authority should be allocated to the lowest competent institutional unit (Vanberg 1997b). In combination with a consequent advocacy of the idea of the European Single Market with its goal of implementing the four freedoms (free movement of goods, capital, services, and labor), the principle of subsidiarity will incentivize European nations to find local solutions in order to avoid the exit of mobile factors of production, capital and consumers. Facing disruptions caused by technological progress and global integration, national and communal programs aimed at human capital investment and activating labor market programs (e.g., access to programs of life-long learning) are likely to be more effective than industrial or agricultural policies trying to preserve inefficient branches of the economy through large-scale subsidization at the national or European level. However, the subsidiarity principle does not rule out the feasibility of policies at the supranational level. On the contrary, it seems necessary to coordinate such measures at the European level in order to secure worker mobility and an incentive-compatible

\footnotetext{
${ }^{26}$ The main reason is that many market players will find it more profitable to invest in rent-seeking activities (e.g., lobbying for protectionist measures or higher subsidies) rather than selling consumers better and cheaper products. For ordoliberals, economic power and political power are two sides of the same (problematic) coin.
} 
harmonization of the regulatory framework. ${ }^{27}$ Ultimately, the subsidiarity principle will help to decide which programs should be located at the communal, national, or supranational level.

\subsection{The crucial role of political participation}

In the years since the last financial crisis, the European Commission (together with the International Monetary Fund and the European Central Bank) reacted with several bailout packages to address the severe economic situations in the economies of the European periphery. At the time, many experts thought of those packages as plausible and necessary in the face of the crisis's magnitude. However, to many citizens of those countries the economic programs felt externally imposed. That feeling, in combination with the lingering crisis, has led to a fundamental erosion of trust in European political institutions on behalf of citizens in the crisis-affected countries and in the core countries of the European Union (Algan et al. 2017).

Against that backdrop, a contemporary ordoliberalism should reconsider which actors and institutions dominate the European policy agenda. All too often, rent-seeking groups in the private sector wield disproportionate political influence, e.g., when big banks or pharmaceutical companies set their own regulatory standards (Rodrik 2018). As a result, many Europeans understandably do not see economic elites as part of the solution, but as the cause of the current crisis (The Economist 2018). It seems plausible to assume that trust in a liberal economic order will erode further if consumers conclude that they do not have equal say in setting the rules of the economic game (think of the negative public reaction to the negotiations of the Transatlantic Trade and Investment Partnership, TTIP, between the EU and the US). In practical terms, contemporary ordoliberals must be sensitive to the question of who is given a stake when pivotal economic policies in trade, finance, and industrial policy are negotiated between the EU and its nation states. A modern ordoliberalist has to think more carefully about institutional reforms that do not only take consumer sovereignty but also citizen sovereignty seriously. Doing so requires a comparative analysis of ways in which democratic norms of representation, participation, and deliberation can be realized on the European level. Europe will end up with a true European community only if it is able to establish a regime that enables economic governance by discussion and not by top-down crisis politics.

\section{Conclusion}

In this paper, we presented a detailed view on the current battle of ideas that originated in the aftermath of the Eurozone crisis. In that battle, ordoliberalism has been identified both as the cause of and the answer to the many economic challenges that continue to exist in

\footnotetext{
27 An example of an incentive-compatible harmonization is the principle of delayed integration as a rule for taxing migrants (Richter 2004; Weichenrieder and Busch 2007). In order to avoid a race-to-the-bottom dynamic in the tax systems stemming from the mobility of not only workers but also potential welfare recipients, delayed integration requires that emigrating workers have to continue paying taxes in their home countries for a certain period and immigrants be taxed in the host country only after a period of transition. According to proponents of that plan, implementing it changes governments' incentives regarding their tax plans in a way that may limit negative tax competition.
} 
Europe. In order to understand the debate, we argued that one has to delve deeper into the issue of ideological uses and abuses of ordoliberal ideas. We suggested that many critics simplify ordoliberal thoughts in order to advocate their own ideological positions. However, ordoliberals likewise have contributed to the ideological battle by simply repeating mantras from the past without actively trying to develop a dynamic research agenda. We think that the latter can be realized if contemporary ordoliberals focus on their normative core of consumer and citizen sovereignty and translate it into feasible policy proposals that tackle the most pressing socioeconomic imbalances of the European Union.

Ordoliberalism is built on the core idea that the coordination of economic interactions in a complex system requires a deep understanding of the essential role of moral and political thinking. And, as Landmann (2019, p. 164) points our concisely, "[the] Eurozone is such a complex system - a system badly in need of a shared political determination of Europeans to cooperate towards financial and macroeconomic stability". Facing the recent populist backlash against openness and international coordination, ordoliberal policy proposals might help to regain public support for market integration by increasing democratic control of national and European economic policies. After decades in which economists often neglected fundamental social questions in favor of technocratic details, ordoliberals can offer an attractive political economy framework.

Acknowledgements Paper presented at the conference "The Freiburg School and the Virginia School: The Research Programs of Ordnungspolitik and Constitutional Political Economy", Freiburg, December 6-9, 2018. The authors would like to thank the Walter Eucken Institute for organizing the conference. They are grateful to the journal's editor, guest editors, two anonymous reviewers and the conference participants for their most helpful discussions and suggestions.

Funding Open Access funding enabled and organized by Projekt DEAL. No funding was received for conducting this study.

Code availability Not applicable.

\section{Compliance with ethical standards}

Conflict of interest The authors have no conflicts of interest to declare that are relevant to the content of this article.

Availability of data and material Not applicable.

Open Access This article is licensed under a Creative Commons Attribution 4.0 International License, which permits use, sharing, adaptation, distribution and reproduction in any medium or format, as long as you give appropriate credit to the original author(s) and the source, provide a link to the Creative Commons licence, and indicate if changes were made. The images or other third party material in this article are included in the article's Creative Commons licence, unless indicated otherwise in a credit line to the material. If material is not included in the article's Creative Commons licence and your intended use is not permitted by statutory regulation or exceeds the permitted use, you will need to obtain permission directly from the copyright holder. To view a copy of this licence, visit http://creativecommons.org/licenses/by/4.0/.

\section{References}

Albert, M. (1993). Capitalism versus capitalism: How America's obsession with individual achievement and short-term profit has led it to the brink of collapse. New York: Four Walls Eight Windows. 
Algan, Y., Guriev, S., Papaioannou, E., \& Passari, E. (2017). The European trust crisis and the rise of populism. Brookings Papers on Economic Activity, 2017(2), 309-400.

Art, D. (2015). The German rescue of the Eurozone: How Germany is getting the Europe it always wanted. Political Science Quarterly, 130, 181-212.

Bachmann, R. (2019). Ordoliberalism from the perspective of a US-trained macroeconomist. In M. Dold \& T. Krieger (Eds.), Ordoliberalism and European economic policy: Between realpolitik and economic utopia. Abingdon and New York: Routledge.

Becker, J., \& Fuest, C. (2017). Der Odysseus-Komplex. Ein pragmatischer Vorschlag zur Lösung der Eurokrise. München: Carl Hanser Verlag.

Berghahn, V., \& Young, B. (2013). Reflections on Werner Bonefeld's 'Freedom and the strong state: On German ordoliberalism' and the continuing importance of the ideas of ordoliberalism to understand Germany's (contested) role in resolving the Eurozone crisis. New Political Economy, 18, 768-778.

Berthold, N. (2017). Wachstumsschwäche, Arbeitslosigkeit und Populisten in Europa. Gewinnt der „Club Med“ die Schlacht der Ideen? Wirtschaftliche Freiheit, 2 June 2017. http://wirtschaftliche freiheit.de/wordpress/?p=20927.

Biebricher, T. (2013). Europe and the political philosophy of neoliberalism. Contemporary Political Theory, 12, 338-375.

Blyth, M. (2015). Austerity: The history of a dangerous idea. Oxford: Oxford University Press.

Böhm, F. (1960). Reden und Schriften. Karlsruhe: C.F. Müller.

Bonefeld, W. (2012). Freedom and the strong state: On German ordoliberalism. New Political Economy, $17,633-656$.

Braunberger, G. (2016). Ordnungsökonomik ist nicht genug: unsystematische Beobachtungen eines Wirtschaftsjournalisten. In J. Zweynert, S. Kolev, \& N. Goldschmidt (Eds.), Neue Ordnungsökonomik. Mohr Siebeck: Tübingen.

Brunnermeier, M. K., James, H., \& Landau, J. P. (2016). The euro and the battle of ideas. Princeton: Princeton University Press.

Brunnermeier, M. K., \& Morgan, J. (2010). Clock games: Theory and experiments. Games and Economic Behavior, 68, 532-550.

Buchanan, J. M. (1987). The constitution of economic policy. American Economic Review, 77, 243-250.

Bulow, J., \& Klemperer, P. (1999). The generalized war of attrition. American Economic Review, 89, 175-189.

Burda, M. (2015). Letter from Germany - Dispelling three myths on economics in Germany. RES Newsletter No. 170, July 2015. http://www.res.org.uk/view/art1July15Corresp.html.

Der Spiegel (2011). Merkel's clichés debunked by statistics. 19 May 2011. http://www.spiegel.de/inter national/europe/the-myth-of-a-lazy-southern-europe-merkel-s-cliches-debunked-by-statistics -a-763618.html.

Dold, M., \& Krieger, T. (2017a). Competition or conflict? Beyond traditional ordo-liberalism. In C. Joerges \& J. Hien (Eds.), Ordoliberalism, law and the rule of economics. Oxford: Hart Publishing.

Dold, M., \& Krieger, T. (2017b). Ordoliberalism is not responsible for Jihadist terrorism in Europe-A reply to Van der Walt. New Perspectives, 25, 105-115.

Dold, M., \& Krieger, T. (2019a). The 'new' crisis of the liberal order: Populism, socioeconomic imbalances, and the response of contemporary ordoliberalism. Journal of Contextual Economics, 139, $243-258$.

Dold, M., \& Krieger, T. (2019b). Ordoliberalism and Beyond: Economic Liberalism for the 21st Century. In M. Dold \& T. Krieger (Eds.), Ordoliberalism and European economic policy: Between realpolitik and economic utopia. Abingdon and New York: Routledge.

Dold, M., \& Krieger, T. (2019c). Ordoliberalism and European economic policy: An introduction. In M. Dold \& T. Krieger (Eds.), Ordoliberalism and European economic policy: Between realpolitik and economic utopia. Abingdon and New York: Routledge.

Dustmann, C., Fitzenberger, B., Schönberg, U., \& Spitz-Oener, A. (2014). From sick man of Europe to economic superstar: Germany's resurgent economy. Journal of Economic Perspectives, 28, $167-188$.

Dyson, K. (2017). Ordoliberalism as tradition and as ideology. In C. Joerges \& J. Hien (Eds.), Ordoliberalism, law and the rule of economics. Oxford: Hart Publishing.

Dyson, K. (2019). Ordoliberalism and the cross-national disciplinary revolution in liberalism. In M. Dold \& T. Krieger (Eds.), Ordoliberalism and European economic policy: Between realpolitik and economic utopia. Abingdon and New York: Routledge.

The Economist (2018). The Economist at 175: Reinventing liberalism for the 21st century. Print edition, 13 Sept 2018, 45-54.

Eucken, W. (1949). Die Wettbewerbsordnung und ihre Verwirklichung. ORDO, 2, 1-99. 
Eucken, W. (1952/2004). Grundsätze der Wirtschaftspolitik. 7th edition. Tübingen: Mohr (Siebeck).

Feld, L. P., Köhler, E. A., \& Nientiedt, D. (2015). Ordoliberalism, pragmatism and the Eurozone crisis: How the German tradition shaped economic policy in Europe. European Review of International Studies, 2, 48-61.

Fisher, I. (1919). Economists in public service: Annual address of the President. American Economic Review, 9, 5-21.

Foucault, M. (2008). The birth of biopolitics: Lectures at the Collège de France, 1978-1979. New York: Palgrave.

Freeden, M. (2006). Ideology and political theory. Journal of Political Ideologies, 11, 3-22.

Friedman, M. (1953). The methodology of positive economics. In M. Friedman \& M. Friedman (Eds.), Essays in positive economics. Chicago: University of Chicago Press.

Fudenberg, D., \& Tirole, J. (1991). Game theory. Cambridge, MA: MIT Press.

Geertz, C. (1973). The interpretation of cultures. New York: Basic Books.

The Economist (2015). Germany and economics. Of rules and order. 9 May 2015. https://www.econo mist.com/europe/2015/05/09/of-rules-and-order.

Hands, D. W. (2001). Reflection without rules: Economic methodology and contemporary science theory. Cambridge: Cambridge University Press.

Heilbroner, R. L. (1988). Rhetoric and ideology. In A. Klamer, D. N. McCloskey, \& R. M. Solow (Eds.), The consequences of economic rhetoric. Cambridge: Cambridge University Press.

Heilbroner, R. L. (1990). Economics as ideology. In W. J. Samuels (Ed.), Economics as discourse: An analysis of the language of economists. New York: Springer Science \& Business Media.

Hien, J. (2017). The European sovereign debt crisis and the danger of ideational monocultures. New Perspectives, 25, 12-21.

Hien, J. (2019). A new Thirty Years' War? The Protestant ordoliberalism and the reemergence of the North-South conflict. In M. Dold \& T. Krieger (Eds.), Ordoliberalism and European economic policy: Between realpolitik and economic utopia. Abingdon and New York: Routledge.

Higgs, R. (2008). The complex course of ideological change. American Journal of Economics and Sociology, 67, 547-565.

Hinich, M. J., \& Munger, M. C. (1996). Ideology and the theory of political choice. Ann Arbor: University of Michigan Press.

Javdani, M., \& Chang, H. J. (2019). Who said or what said? Estimating ideological bias in views among economists. Mimeo. https://ssrn.com/abstract=3356309.

King, J. E. (2015). A post Keynesian critique of Swabian housewife logic. In A. Bitzenis, N. Karagiannis, \& J. Marangos (Eds.), Europe in crisis: Problems, challenges, and alternative perspectives. Basingstoke: Palgrave Macmillan.

Klamer, A., \& McCloskey, D. (1988). Economics in the human conversation. In A. Klamer, D. N. McCloskey, \& R. M. Solow (Eds.), The consequences of economic rhetoric. Cambridge: Cambridge University Press.

Kluth, A. (2018). Ordoliberalism and the alleged aberration of German economics. Handelsblatt, 31 Jan 2018. https://www.handelsblatt.com/today/politics/handelsblatt-explains-ordoliberalism-and-thealleged-aberration-of-german-economics/23580920.html.

Köhler, E. A., \& Kolev, S. (2013). The conjoint quest for a liberal positive program: "Old Chicago", Freiburg, and Hayek. In S. Peart \& D. Levy (Eds.), FA Hayek and the modern economy. New York: Palgrave Macmillan.

Kolev, S. (2018). James Buchanan and the "new economics of order" research program. In R. Wagner (Ed.), James M. Buchanan. Cham: Palgrave Macmillan.

Kolev, S. (2019). Ordoliberalism's embeddedness in the neoliberalisms of the 1930s and 1940. In M. Dold \& T. Krieger (Eds.), Ordoliberalism and European economic policy: Between realpolitik and economic utopia. Abingdon and New York: Routledge.

Krieger, T. (2016). Any solution in sight to Europe's crisis? Some general thoughts from a conflict theoretical perspective. In T. Krieger, B. Neumärker, \& D. Panke (Eds.), Europe's crisis: The conflicttheoretical perspective. Nomos: Baden-Baden.

Krieger, T. (2018). Ordoliberalismus-Bashing? Eine Chance! In N. Kosturkova \& J. Rieger (Eds.), Ordnungspolitisch stets auf Kurs: Festschrift für Norbert Berthold. München: Verlag Franz Vahlen.

Krieger, T., \& Meierrieks, D. (2016). Political capitalism: The interaction between income inequality, economic freedom and democracy. European Journal of Political Economy, 45, 115-132.

Krugman, P. (2014). Ordoarithmetics. New York Times, 1 Oct 2014. https://krugman.blogs.nytim es.com/2014/10/01/ordoarithmetic/. 
Landmann, O. (2019). Germany and the Euro crisis: Ordoliberalism in the dock. In M. Dold \& T. Krieger (Eds.), Ordoliberalism and European economic policy: Between realpolitik and economic utopia. Abingdon and New York: Routledge.

Lucas, R. E., Jr. (1976). Econometric policy evaluation: A critique. Carnegie-Rochester Conference Series on Public Policy, 1, 19-46.

Münchau, W. (2014). The wacky economics of Germany's parallel universe. Financial Times, 16 Nov 2014. https://www.ft.com/content/e257ed96-6b2c-11e4-be68-00144feabdc0.

Osborne, M. J. (2003). An introduction to game theory. Oxford: Oxford University Press.

Palley, T. I. (2015). Money, fiscal policy, and interest rates: A critique of modern monetary theory. Review of Political Economy, 27, 1-23.

Ptak, R. (2009). Neoliberalism in Germany: Revisiting the ordoliberal foundations of the social market economy. In P. Mirowski \& D. Plehwe (Eds.), The road from Mont Pelerin: The making of the neoliberal thought collective. Cambridge, MA: Harvard University Press.

Richter, W. F. (2004). Delaying integration of immigrant labor for the purpose of taxation. Journal of Urban Economics, 55, 597-613.

Rodrik, D. (2018). Populism and the economics of globalization. Journal of International Business Policy, $1,22$.

Ryner, M. (2015). Europe's ordoliberal iron cage: Critical political economy, the euro area crisis and its management. Journal of European Public Policy, 22, 275-294.

Sally, R. (1996). Ordoliberalism and the social market: Classical political economy from Germany. New Political Economy, 1, 233-257.

Schimmelfennig, F. (2015). Liberal intergovernmentalism and the euro area crisis. Journal of European Public Policy, 22, 177-195.

Schumpeter, J. A. (1949). Science and ideology. American Economic Review, 39, 346-359.

Shiller, R. J. (1997). Why do people dislike inflation? In C. Romer \& D. Romer (Eds.), Reducing inflation: Motivation and strategy. Chicago: University of Chicago Press.

Shughart, W. F., \& McChesney, F. S. (2010). Public choice theory and antitrust policy. Public Choice, 142, 385-406.

Sinn, H.-W. (2014). The euro trap: On bursting bubbles, budgets, and beliefs. Oxford: Oxford University Press.

Tribe, K. (1990). Review of 'Germany’s social market economy: Origins and evolution' by Alan Peacock and Hans Willgerodt. Economic Journal, 100, 630-632.

Van der Walt, J. (2016). When one religious extremism unmasks another: Reflections on Europe's states of emergency as a legacy of ordo-liberal de-hermeneuticisation. New Perspectives, 24, 79-101.

Vanberg, V. (1997a). Die normativen Grundlagen von Ordnungspolitik. ORDO: Jahrbuch für die Ordnung von Wirtschaft und Gesellschaft, 48, 707-726.

Vanberg, V. (1997b). Subsidiarity, responsive government and individual liberty. In B. Steunenberg \& F. van Vught (Eds.), Political institutions and public policy. Dordrecht: Springer.

Vanberg, V. (2005). Market and state: The perspective of constitutional political economy. Journal of Institutional Economics, 1, 23-49.

Vanberg, V. (2015). Ordoliberalism, Ordnungspolitik, and the reason of rules. European Review of International Studies, 2, 27-36.

Vanberg, V. J. (2017). Ordoliberalism and Ordnungspolitik: A brief explanation. Freiburg: Aktionskreis Freiburger Schule.

Weichenrieder, A. J., \& Busch, O. (2007). Delayed integration as a possible remedy for the race to the bottom. Journal of Urban Economics, 61, 565-575.

Weintraub, E. R. (1990). Comment. In W. J. Samuels (Ed.), Economics as discourse: An analysis of the language of economists. New York: Springer Science \& Business Media.

Young, B. (2015). Introduction: The hijacking of German ordoliberalism. European Review of International Studies, 2, 7-15.

Young, B. (2017). What is neoliberal in Germany's and Europe's crisis politics? In C. Joerges \& J. Hien (Eds.), Ordoliberalism, law and the rule of economics. Oxford: Hart Publishing.

Zestos, G. K. (2015). The global financial crisis: From US subprime mortgages to European sovereign debt. Abingdon: Routledge.

Publisher's Note Springer Nature remains neutral with regard to jurisdictional claims in published maps and institutional affiliations. 